\title{
Evaluating 'Life Steeped in Power': Non-Domination, the Rule of Law and Spatial Restrictions for Irregular Migrants
}

\section{Lieneke Slingenberg ${ }^{1}$}

Accepted: 26 September 2020 / Published online: 12 October 2020

(c) The Author(s) 2020

\begin{abstract}
Irregular migrants in Europe are increasingly subjected to state coercion, surveillance and spatial restrictions, such as containment, dispersal and forced transfers. Lawyers usually evaluate such practices in the light of human rights law, which only provides limited protection. For this reason, I propose an alternative normative framework to evaluate and assess coercive state practices towards irregular migrants: the concept of freedom as non-domination. In this article, I conceptualize non-domination from a rule of law perspective. To this end, I start from Lovett's procedural account of arbitrariness; and complement this with Benton's focus on unaccountable power and Palombella's argument for 'duality of law'. In the second part of this article, I apply this normative framework to coercive practices in shelters for irregular migrants in the Netherlands. This allows me to demonstrate the practical relevance and consequences of the theory. It discloses how the protection of freedom as nondomination, conceptualized from a rule of law perspective, sets more demanding criteria for the (courts of) law than the protection of human rights. At the same time, it does not require non-interference or elaborate positive obligations from the state. For irregular migrants, who do not have the right to reside in the territory, but who are entirely under the control of state power, non-domination as conceptualized in this paper provides, in my view, a necessary framework of review that ensures a kind of protection that is currently lacking.
\end{abstract}

Keywords Non-domination $\cdot$ Rule of law $\cdot$ Accountability mechanisms $\cdot$ Legal remedies $\cdot$ Irregular migrants $\cdot$ Shelters

Lieneke Slingenberg

c.h.slingenberg@vu.nl

1 Amsterdam Centre for Migration and Refugee Law, Vrije Universiteit Amsterdam, Amsterdam, The Netherlands 


\section{Introduction}

Irregular migrants and asylum seekers in Europe are increasingly subjected to detention and spatial restrictions, such as containment, dispersal and forced transfers within the territory. ${ }^{1}$ Prominent examples are the confinement of asylum seekers at the Greek islands ${ }^{2}$ and the German residenzpflicht ${ }^{3}$ It is also visible in the Netherlands, where migrants with minor children, lacking legal residence, are housed in state-funded shelters, so-called 'family locations' (gezinslocaties). The families living in these shelters are subjected to forced transfers, a daily reporting duty and a geographical restriction (prohibition to leave the territory of the municipality in which the shelter is located).

Legal literature on the position of migrants without legal residence focusses mainly on migrants' formal exclusion from state funded benefits. It examines whether and to what extent the state is legally obliged to provide migrants without legal residence with shelter, health care, education or other kind of basic needs. If attention is payed to their inclusion in these kinds of benefits, this is mainly done from a human rights or comparative perspective. It is emphasized how states, by providing only limited and highly conditional benefits to migrants without legal residence, fail in meeting their positive obligations under human rights law or in reaching some level of harmonization within the EU. ${ }^{4}$ The coercion involved in such inclusionary practises is rarely analysed as such.

While human rights law is a relevant framework for assessing such practises, it has also been argued that human rights law can only provide limited protection for irregular migrants, since human rights 'seduce us to locate responsibility for the absence of protection with the individual undocumented migrant rather than the state' ${ }^{5}$; because in the context of migration, equal human rights protection should always be weighed against the sovereignty of the state ${ }^{6}$ or since human rights can be used to justify restrictive migration policies. ${ }^{7}$ In line with this, as this paper will also show, many of the relevant human rights provisions only apply to migrants who are 'lawfully within the territory', and, consequently, exclude migrants without legal residence entirely from their scope of application.

For this reason, I propose an alternative normative framework to evaluate practices in which the provision of basic needs is made conditional on irregular migrants' subjection to coercion: the concept of freedom as non-domination. In this paper, I conceptualize non-domination from a rule of law perspective. To this end, I start

\footnotetext{
1 Campesi 2018; ECRE 2018; Kreichauf 2018; Majcher, Flynn and Grange 2020; Tazzioli 2020.

2 ECRE 2020a, p. 144-148.

3 ECRE 2020b, p. 80-81; McDonough 2009.

4 Da Lomba 2011, Kapuy 2011, Schoukens and Buttiens 2017, Spencer and Hughes 2015.

5 Noll 2010. Cf. Dembour in her concluding chapter, where she argues that the European Court of Human Rights 'tends to regard migrant applicants as solely responsible for the problematic situation they are in' and 'fails to see that they are evolving within a structure of inequality which limits their options'(Dembour 2015, p. 504).

6 Bosniak 2006.

7 Moreno-Lax 2018.
} 
from Lovett's procedural account of arbitrariness ${ }^{8}$ but complement this with Benton's focus on unaccountable power ${ }^{9}$ and Palombella's argument for 'duality of law' as a fundamental requirement of the rule of law. ${ }^{10}$ In the second part of this paper, I apply this normative framework to coercive practices in the family locations for irregular migrants in the Netherlands in order to demonstrate the practical relevance and consequences of the theory. It focusses in particular on the daily reporting obligation to which migrants living in family locations are subjected. This case study serves as an example of the coercive practices and spatial restrictions that migrants without lawful residence are increasingly subjected to throughout Europe. ${ }^{11}$ It shows that the concept of freedom as non-domination as conceptualized in this paper goes beyond the limited protection that human rights law can provide against these kind of coercive bordering practices.

\section{The Rule of Law: a Republican Perspective}

\subsection{Non-Domination and the Rule of Law}

The concept of freedom as non-domination is an historical concept that has its origins in the classical republican tradition, with figures such as Machiavelli, Milton, Montesquieu, Blackstone, Jefferson and Madison. There has recently been renewed interest in the concept of freedom as non-domination by, what is often called, 'neo-republicanism'. ${ }^{12}$ Freedom in terms of non-domination is about the absence of mastery by others and can, therefore, be contrasted with both freedom as noninterference (negative freedom) and freedom as self-mastery (positive freedom). ${ }^{13}$ In neorepublican theory, mastery, or 'domination', is understood as subjection to a threat of arbitrary, or uncontrolled, interferences. Domination is the kind of power no one ${ }^{14}$ should be subjected to, even if this power is not being used or only used for legitimate reasons. ${ }^{15}$

\footnotetext{
${ }^{8}$ Lovett 2010, 2016 and 2020.

9 Benton 2010 and 2014.

10 Palombella 2009, 2010 and 2018.

11 See footnote 1 above.

12 Lovett 2010; Pettit 1997 and 2012; Shapiro 2012.

13 Petit 1999, p. 22.

14 Traditionally, neorepublican theory places a lot of emphasis on citizenship, asserting that a 'free state' should promote its citizens' freedom from domination (Lovett and Pettit, p. 12). In contrast, Lovett argues that this obligation applies to everybody who is affected by the power of the dominator 'regardless of community membership', since it has become 'increasingly obvious' that the persons affected by a community's institutions and practices are not coextensive with the members of that community (Lovett 2010, pp. 172-173). Theorists on the ethics of migration have elaborated on this issue further (see for example the special issue of the Critical Review of International Social and Political Philosophy on Domination, Migration and Non-citizens (2014, volume 17, no. 1). They have argued that non-domination theory is indeed a relevant theory to address the issue of migration, in particular the treatment of non-citizens present in the territory (E.g. Fine 2014; Hovdal-Moan 2014; Benton 2014).

15 Lovett and Petit 2009.
} 
With regard to the issue of what type of control or constraint is required to prevent an interference from becoming domination, two main views have been put forward: a substantive (or democratic) one and a procedural one. Following Arnold and Harris, ${ }^{16}$ the substantive view can be divided into 'interest substantivism', where power is sufficiently constrained if the power holder is forced to track the interests of the power subjects ${ }^{17}$; and 'control substantivism', where power is sufficiently constrained if it is governed by the direct influence of the power subjects. ${ }^{18}$ The procedural view is mainly developed by Lovett. This view equates republican freedom with the traditional idea of the rule of law, "provided of course that we are willing to loosen and extend this idea considerably'. ${ }^{19}$ Since migrants usually lack the right to vote and cannot, therefore, exercise full democratic control, the procedural 'rule of law' view seems, at first sight, most relevant to reduce migrants' domination.

Much has been written about the rule of law. It is widely accepted as a fundamental value and a crucial element of the legitimacy of a state. It has been described as 'the most powerful and often repeated political ideal in contemporary global discourse $^{, 20}$ and as the 'the most important political ideals of our time'. ${ }^{21}$ Most of the literature on the rule of law does not, however, (elaborately) deal with the virtues or functions of the rule of law. Instead, it focusses on the requirements for legal systems that result from the rule of law. Lists of features or elements of the rule of law are drawn up, often distinguishing thin (minimalist, formal) and thick (maximalist, substantive) versions of the rule of law. Thick versions of the rule of law usually include values such as democracy and recognition of social and civil human rights; whereas thin versions merely require procedural safeguards and legality. It is, however, widely accepted that both these versions experience difficulties is justifying their importance. ${ }^{22}$

Lovett argues why in his conceptualization, the rule of law is not redundant (as in thick versions of the rule of law) nor relatively trivial (as in thin versions of the rule of law). He defends the procedural view on arbitrariness, or, in other words, the value of the rule of law, by arguing that the law can govern the use of coercive force

\footnotetext{
16 Arnold and Harris 2017.

17 Petit 1997.

18 Petit 2012.

19 Lovett 2016, p. 112.

20 Tamanaha 2012, p. 232.

21 Waldron 2008.

22 The problem with thick versions of the rule of law is that they overlap with a complete philosophy for social justice. The justification for the rule of law, then, risks being a circular reasoning, as the rule of law is good in this account, since only 'good laws' fit in the model. As Joseph Raz puts it, '[w]e have no need to be converted to the rule of law just in order to discover that to believe in it is to believe that good should triumph (Raz 1979, p. 211). See also Tamahana, who argues that "when one reads all the rhetoric about the rule of law that now exists, it sometimes sounds like the rule of law is the essential basis of all good things' (Tamahana 2012, p. 235). On the other hand, Raz also stresses the limitations of a thin version of the rule of law, as in such a thin version, the rule of law is compatible with gross violations of human rights. The law may, for example, 'institute slavery without violating the rule of law' (Raz 1979, p. 221).
} 
effectively and reliably in a way alternative practices cannot. ${ }^{23}$ In his conceptualization of the rule of law, people should not be exposed to coercive force except as the consequence of their having failed to observe a legally valid prescriptive rule. In that way, people can avoid being exposed to coercive force by observing the rule without depending on the good will of other human agents. ${ }^{24}$

This implies, according to Lovett, that three broad criteria should be met for a society to have the rule of law:

1. Every use of coercive force in that society is governed by rules (i.e. not a command).

2. The rules governing the use of coercive force in that society must be effective and reliable (i.e. there must be a high degree of probability that it will be observed and this probability must be robust).

3. It must be common knowledge in that society both (a) what rules govern the use of coercive force, and (b) that those rules are effective and reliable (i.e. the rules must be published, sufficiently clear and reasonably stable). ${ }^{25}$

Lovett's proceduralism has been criticised in the context of discriminatory laws and regulations (apartheid regimes, discriminatory admission policies) ${ }^{26}$ and, most relevant for the topic of this paper, in the context of 'total institutions'. These critiques have in common that Lovett's procedural account of arbitrariness does not prevent situations of 'rule-bound domination', ${ }^{27}$ where the rules themselves are a source of domination. Drawing on Goffman's definition of total institutions, according to which total institutions are closed to the outside world, where every sphere of the inmates' lives is highly regimented and homogenised, Lazar for example stresses that such institutions need not be arbitrary in the procedural sense. Such institutions can be governed in conformity with the conditions for the rule of law as provided by Lovett. Nevertheless, it is common knowledge that such institutions causes its residences 'radical and intolerable levels of anxiety and stress, a degradation of self and of agency', which is a similar bundle of psychological effects as present in paradigm cases of domination, such as slavery. Lazar concludes for this reason that wholly procedural accounts of arbitrariness should be rejected. ${ }^{28}$ In the same vein, Arnold and Harris argue that a procedural account would prefer, for example, an university admission policy that clearly stipulates that all minority students should be rejected over an admission policy where administrators have discretion whether to expel students. They conclude as well that, with such 'absurd results', proceduralism should be rejected. ${ }^{29}$

\footnotetext{
23 Lovett 2016, p. 118.

24 Lovett 2020, p. 11-12.

25 Lovett 2016, p. 128-132.

26 Arnold and Harris 2017, p. 59; Blunt 2015, p. 14-17. See, similarly, but using reforms to slavery laws as an example, McCammon 2015, p. 1045-1050.

27 Lazar 2019.

28 Lazar 2019, p. 698.

29 Arnold and Harris 2017, p. 59. Cf. Blunt 2015, p. 17.
} 
Lovett responds to this criticism in his more recent work, albeit not directly. He explains that in his conceptualization, the rule of law should not be understood as a virtue of legal systems, but rather as a virtue of social orderings: 'societies enjoy the rule of law to the extent that all public and private uses of coercive force are managed through the mode of law, ${ }^{30}$ This means that the law must do more than merely 'grant a stamp of legal approval' to the use of coercive force. It must 'articulate a set of impersonal public rules such that, provided people undertake a reasonable effort to follow those rules, they will not ordinarily be subjected to violence or physical restraint at the hands of others' ${ }^{31}$ In other words, discretionary use of coercive force should be reduced; merely approving it by law is not enough. In this way, a discriminatory admission policy or an apartheid or slave law regime does not meet these criteria, as it merely authorizes the use of coercive force, it does not ensure that people can avoid being subjected to violence or physical restraint by following the rules. ${ }^{32}$

This begs the question, however, whether all situations in which observing a rule implies subjecting oneself to coercive force i.e. where observing a rule involves considerable physical restraint, cannot be reconciled with the rule of law. This would be rather far-stretching as following a rule often involves some kind of restraint. This resembles the second kind of critique of Arnold and Harris, who argue that proceduralism is also excessively demanding in requiring that every kind of discretion should be banned. ${ }^{33}$

Again, in his more recent work Lovett provides a response to this criticism, by distinguishing between different sorts of discretion and stressing that not every kind of discretion is in violation with the idea of the rule of law. Under certain conditions, 'rule-implementing discretion', i.e. the discretionary judgement that is necessary to apply any given rule to a particular situation, ${ }^{34}$ can be reconciled with the rule of law. This is, however, not true for cases of 'strong discretion', where constraints are absent altogether, and for 'accountability discretion'. To prevent accountability discretion, Lovett stresses the need for accountability mechanisms for rule makers. ${ }^{35}$ He does, however, not elaborately conceptualize such accountability mechanisms. On this point, I believe that Benton's theory is relevant, as she deals with accountability mechanisms much more elaborately. She provides an alternative model of arbitrariness, entirely based on accountability instead of control. She defines arbitrary power as unaccountable power and proposes to identify accountability gaps. These exist, according to Benton:

where there are insufficient checking mechanisms which require that:

\footnotetext{
30 Lovett 2020, p. 13.

31 Lovett 2020, p. 14.

32 In this way, I would say, Lovett does acknowledge the systemic elements of domination (see, to the contrary, Blunt 2015).

33 Arnold and Harris 2017, p. 59-60.

34 Lovett fully appreciates the dynamic character of law. The law should, in his view, not be seen as a complete and internally coherent system that supplies every legal question with a clear and determinate answer. This 'deeply implausible' kind of legal formalism can simply not be true, due to the inherent ambiguity, internal contradictions and incompleteness of any rule (Lovett 2016, p. 153).

35 Lovett 2016, p. 187; Lovett 2020 p. 16-17.
} 
- state power is justified to all subjects of the power (justification);

- subjects of the power are able to complain if their interests are not being met (contestation); and

- power-holders are duly punished if they fail to track the interests of power-subjects (retribution). ${ }^{36}$

Benton stresses the limited and mostly procedural nature of these requirements. Accountability mechanisms should be seen, in her view, as 'systematic questions asked of the exercise of power'. She argues that it is the existence of the questions rather than a positive answer to them that makes power non-arbitrary. ${ }^{37}$

In my view, Benton's theory does not depart that far from Lovett's theory on the rule of law. Lovett stresses the need for accountability mechanisms for rule-makers (legislators, administrative agencies and judges) as well and argues that 'accountability discretion' (cf. Benton's accountability gaps) cannot be reconciled with the rule of law. However, Benton's conceptualization of accountability mechanisms is more demanding then Lovett's definition. Lovett does not require accountability mechanisms to justify the use of power or to include possibilities to contest but limits it to requiring the punishment of rule-makers for not following public and orderly procedures that define and limit the scope of the legislative authority. ${ }^{38}$

In this way, Benton's concept of unaccountable power serves as a relevant addition to Lovett's theory that can help meet the critique that his theory covers not enough (e.g. apartheid, discriminatory admission policies) and, at the same time, covers too much (every kind of discretionary use of (coercive) power). The next section will discuss Benton's definition of accountability mechanisms in more detail.

\subsection{Protection Against Dependence on Unaccountable Power: Judicial Control}

The foregoing section showed that accountability mechanisms should ensure that the rules are justified to the subjects of the coercive power; that there are means to contest the rules; and that there is a possibility to impose a sanction on the rule-makers for not following the correct procedures for law-making or for failing to track the interests of power subjects.

Contestation requires, as Benton argues, that accountability is at least to some extent self-initiated or self-controlled; external checking mechanisms are not enough. The importance and need of this element of 'voice' increases to the extent that exit from the power of the state becomes prohibitively costly or infeasible. ${ }^{39} \mathrm{By}$

\footnotetext{
36 Benton 2010, p. 408 and Benton 2014, p. 52.

37 Benton 2014, p. 52. This resembles what Waldron calls the procedural understanding of the rule of law. 'The procedural side of the Rule of Law presents a mode of governance that allows people a voice, a way of intervening on their own behalf in confrontations with power. It requires that public institutions sponsor and facilitate reasoned argument in human affairs'. As Waldron explains, this procedural account of the rule of law better fits a concept of law that stresses its inherent argumentative character (Waldron 2008).

38 Lovett 2016, p. 187.

39 Benton 2014, p. 62.
} 
emphasizing the relevance of the possibility to exit the power of the state, Benton refers to Lovett's theory on domination. ${ }^{40}$ According to Lovett, domination should be understood structurally: it must as a minimum include some level of dependency of a person or group on the power-holder. The level of dependency should be measured by taking into account the 'net expected costs (i.e. expected costs less any expected gains) of exiting, or attempting to exit, a social relationship'. ${ }^{41}$ Lovett stresses that the concept of 'exit costs' should be understood broadly; it is not limited to material costs, instead, exit costs are often to some extent psychological and thus subjective. ${ }^{42}$ For Lovett, joined by Benton, dependency is a necessary condition for domination and the greater the dependency of the subjected person is, the more severe the domination will be.

Accountability mechanisms can have many forms. Benton mentions regular and open elections and a free press as examples of mechanisms that can help ensure justification and retribution. ${ }^{43}$ Even for migrants, who do not have the right to vote, such political accountability mechanisms will help to slightly reduce the accountability gap, since representatives might have good reasons to track their interests, as potential future voters, or the interests of their family or community members who can vote. ${ }^{44}$ However, in order to ensure the possibility to contest, which should be to some extent self-initiated, other mechanisms are necessary. Benton mentions diplomatic protection and human rights courts as examples of such mechanisms. ${ }^{45}$

Given the limits of diplomatic protection, ${ }^{46}$ I would argue that for ensuring selfinitiated possibilities to contest, legal accountability mechanisms, in other words judicial control, are necessary. Even though Benton does not elaborately discuss judicial control as an important accountability mechanism, I believe judicial control fits her emphasis on the importance of asking systematic questions of the exercise of power very well. ${ }^{47}$ As Kumm has argued, human rights or constitutional courts often employ a proportionality test. In that process, courts do not primarily interpret authority, but they ask questions and asses the coherence of the arguments and the answers that the parties provide. ${ }^{48}$

\footnotetext{
40 Benton 2014, p. 53.

41 Lovett 2010, p. 39.

42 Lovett 2010, p. 39. As example, Lovett discusses the dependency women can have on their marriage. Exit costs can be high through legal, financial and/or cultural difficulties in divorce, but also through a thorough personal convincement that a woman's highest possible calling is motherhood within a traditional relationship (at p. 50-51).

43 Benton 2014, p. 62.

44 Benton 2014, p. 54-55.

45 Benton 2014, p. 62.

46 E.g. it does not exist at the local level; it depends on the power and willingness of the country of origin, for forced migrants this option does not exist, and it depends on the nature of the interests at stake (Benton 2014, p. 63).

47 Cf. Vinx who argues that judicial review might be a particularly effective opportunity to contest a majority's decision (Vinx 2009, p. 597) and Walen who holds that judicial review serves the crucial function of giving individuals the standing to call the government to account (Walen 2009).

48 Kumm 2010. Also Palombella argues that proportionality is a useful tool for preserving the logic of the rule of law (Palombella 2009, p. 40). See further Sect. 2.3.
} 
A right to contest coercive rules can be further operationalized by making a distinction between two aspects: (1) subjects of such rules should have access to legal remedies and (2) there should be legal grounds on the basis of which the rules can be contested, which constrain the discretion of the rule-makers. For this latter aspect, the idea of 'duality of law', as emphasized by Palombella as a fundamental element of the rule of law, is relevant.

\subsection{Duality of Law}

Palombella discusses the normative meaning of the rule of law by tracing it back to its (mainly English) origins and contrasting it with the continental concept of the Rechtsstaat. The original concept of the Rechtsstaat, he argues, simply meant that law is the structure of the state, not an external limitation to it. In the Rechtsstaat, with its strong emphasis on legality, '[1]aw turns out to be the authentic voice of the State, through which it expresses its own will: it is not the constraint but rather the "form" of the State's will' 49 In contrast, under the rule of law, the state is subordinated to an autonomous law that is not entirely its own. Palombella clearly summarizes this distinction by stating that 'while the Rechtsstaat or l'Etat de droit defeated the ultimate absolute power of the King, because it was the King's, the rule of law defeated it because it was absolute'. ${ }^{50}$

The rule of law depends, according to Palombella, on a 'foundational balance' between gubernaculum and jurisdictio. Gubernaculum is the legitimate sovereign law, at the disposal of the powerful ruler, embracing instrumental aims and government policies, whereas jurisdictio, 'the fundamental law of the land', is a law otherwise developed, that the ruler cannot change at his will. ${ }^{51}$ This other, autonomous law should be located somehow outside the purview of the government, be it granted by the long standing tradition of common law or customary law as reflected in case law or by the creation of a constitutional higher law or convention. ${ }^{52}$ It is not a static law, instead, jurisdiction is a complex and collective construct, made by many hands, trough the wisdom of decades or centuries, and, therefore, itself artificial'. ${ }^{53}$ The rule of law ideal requires respect for and protection of the opposition between these two sides of the law. ${ }^{54}$

For Palombella, legality is a necessary but insufficient element of the rule of law. At the same time, he stresses that the rule of law cannot be conflated with the rule of 'good law'. Instead, the rule of law requires protection of social normativity from being monopolized by one legal source. In other words, the law should not be dictated by an unconstrained choice made by the will of the rulers and reflect

\footnotetext{
49 Palombella 2010, p. 14.

50 Paolombella 2010, p. 18.

51 Palombella 2018, p. 15.

52 Palombella 2010, p. 32.

53 Palombella 2010, p. 20.

54 Palombella 2009, p. 29.
} 
exclusively one conception of the 'good'; it should be contrasted and weighed against a legally separate and independent defense of the 'right'. 55

In short, the rule of law, as argued by Palombella, is about the non-monopolization of legal sources and the safeguard of the tension between the legitimate sovereign law and a law otherwise developed. ${ }^{56}$ Palombella links this conceptualization of the rule of law with the ideal of non-domination. When the rule of law is embedded in the equilibrium of the relation between jurisdictio and gubernaculum, nonarbitrariness on the part of the government obtains and in this situation, 'the ideal of the rule of law can be described as a non-domination principle'. ${ }^{57}$ By insisting on this requisite balance-relation, the rule of law ideal prevents the law from 'turning itself into a sheer tool of domination, ${ }^{58}$ as not even the democratic sovereign "should be allowed to be the ultimate, and thus discretionary, "master" of laws' 59

\subsection{Conclusion}

Drawing on Lovett, Benton and Palombella, I suggest a particular conceptualization of the ideal of freedom as non-domination to evaluate coercive practises against irregular migrants. This conceptualization can be summarised as follows:

Domination is the situation in which a person is:

- subjected to coercive rules;

- from which s/he can only exit at high costs; and

- that have no legal basis and/or cannot be contested in court on the basis of laws stemming from legal sources that are somehow independent from the sovereign power.

In other words: in order to prevent domination, the use of coercive force should be governed by sufficiently reliable and clear public rules. In addition, mechanisms should exist for holding rule-makers accountable. Such accountability mechanisms should at least to some extent be self-initiated or self-controlled. The less possibilities there are to exit the power of the rule-maker, the more important this element of 'voice' is. Judicial control is an important way to ensure a self-initiated possibility to contest coercive rules. For that reason, access to a remedy should be available, as well as grounds of contestation, stemming from jurisdictio, i.e. a legal source that is not primarily developed by the sovereign power.

\footnotetext{
55 Palombella 2010, p. 30.

56 This inherent and important dual character of law, as promoted by Palombella, also meets concerns about judicial review, with judges acting as 'elite agents', becoming another source of arbitrary power and a form of systematic domination itself (see, on the problems of epistocracy for non-domination: Blunt 2020).

57 Palombella 2010, p. 23-27; Palombella 2019, p. 384. Surprisingly, Palombella refers mainly to the work of Petit on non-domination, and not to the work of Lovett.

58 Palombella 2010, p. 6.

59 Palombella 2010, p. 27
} 
The next section will apply this normative framework to coercive practices in shelters for irregular migrants in the Netherlands in order to demonstrate the practical relevance and consequences of the theory.

\section{The Rule of Law and Family Shelters in the Netherlands}

\subsection{Background}

In 1998, the Dutch 'Linkage Act' ${ }^{60}$ entered into force. This act 'linked' migrants' legal status to their entitlement to governmental benefits. Migrants without any kind of legal status or temporary permission to stay were excluded from all state-funded benefits, with the exception of public health and emergency medical care, education for minors and legal aid. The new Aliens Act of 2000 introduced the automatic loss of shelter, four weeks after the final rejection of an asylum application. As a result, rejected asylum seekers were put on the street if they lost their appeal against the rejection of their application, irrespective of whether the authorities were able to actually deport them. In 2007, an exception was created to this full exclusion, for migrants who were about to be expelled and who cooperated with their return procedure. They received shelter in a so-called 'freedom restricting location' (vrijheidsbeperkende locatie, $V B L)$ for a maximum of 12 weeks. $^{61}$

In 2012, the Dutch Supreme Court (Hoge Raad) made an end to this (almost) full exclusion from state-funded shelter for migrants with minor children. The case was about a single mother with three minor children who stayed in a $V B L$. They received shelter under the condition of cooperating in their return to Angola. When the mother refused to cooperate, the authorities wanted to evict the family from the $V B L$. The lawsuit was about the question whether this eviction was lawful. The Court of Appeal of the Hague ruled in 2011 that this eviction was unlawful ${ }^{62}$ and the Hoge Raad upheld this judgment. ${ }^{63}$

In response to these judgments, the Dutch government set up special family shelters (gezinslocaties) in remote places where families with minor children would be housed until the youngest child turns 18. The decision to accommodate these migrants in family locations was announced in a letter to parliament. ${ }^{64}$ The provision of this shelter does not have a basis in Dutch law; there is no Act that provides

\footnotetext{
${ }^{60}$ Wet van 26/03/1998 tot wijziging van de Vreemdelingenwet en enige andere wetten teneinde de aanspraak van vreemdelingen jegens bestuursorganen op verstrekkingen, voorzieningen, uitkeringen, ontheffingen en vergunningen te koppelen aan het rechtmatig verblijf van de vreemdeling in Nederland, Stb 1998, 203.

61 Kamerstukken II, 2006/07, 29,344. no. 61.

62 Court of Appeal of the Hague of 27 October 2010, ECLI:NL:GHSGR:2010:BN2164 and Court of Appeal of the Hague of 11 January 2011, ECLI:NL:GHSGR:2011:BO9924.

63 Hoge Raad 21 september 2012, ECLI:NL:HR:2012:BW5328.

64 Kamerstukken II, 2010/11, 29,344, no. 79.
} 
for the possibility of providing shelter to migrants without legal residence. ${ }^{65}$ On the contrary; it is in clear violation with the Linkage act of 1998 to do so. The absence of a legal basis for the provision of shelter in the family locations has been confirmed by the Council of State. ${ }^{66}$ This means that the authorities have a significant amount of discretion. There is no law that defines and limits the scope of the authorities' power or indicates the aims or goals it is meant to serve.

Yet, in addition to and connected with providing shelter and basic living conditions, the authorities apply measures containing different degrees of coercion to migrants living in family locations. Migrants who are accommodated in family locations are subjected to forced transfers ${ }^{67}$ and to a 'freedom restricting measure'. This measure, based on the Aliens Act $2000,{ }^{68}$ implies that they cannot leave the territory of the municipality in which the family location is established. In addition, they have a weekly reporting obligation with the Aliens police ${ }^{69}$ and a daily reporting obligation (inhuisregistratie) with the authorities of the shelter. In this way, the legal recognition of migrants' deservingness of shelter resulted in a bordering practise involving significant state coercion, surveillance and control.

\subsection{Daily Reporting Obligation}

Migrants living in family locations have to report themselves daily at noon. For children attending school, an exception can be granted. In response to a lot of criticism from NGO's, the reporting duty was revoked for Sundays and public holidays, ${ }^{70}$ and the intention was announced to move the reporting duty on Saturdays towards the end of the afternoon. ${ }^{71}$ In a letter to parliament, the minister justified the daily reporting obligation by stressing the need for the authorities of the shelter to establish the families' presence in the shelter, which ensures their availability for the return procedure. Their presence in the shelter is not only important for organizing formal 'return meetings', but also to 'stay informally in touch with the families'. ${ }^{72}$

\footnotetext{
65 This is quite different for the provision of shelter to asylum seekers. For the reception of asylum seekers, an independent administrative body has been created that has been given the task of providing for the reception of asylum seekers by an act of parliament (Wet Centraal Orgaan Opvang Asielzoekers). This act provides the minister with the competence to adopt a ministerial decree containing the rules with regard to the reception of asylum seekers. This decree lays down the personal scope and the rights and obligations of asylum seekers in a detailed way (Regeling verstrekkingen asielzoekers en andere categorieën vreemdelingen 2005).

66 ABRvS 27 May 2014, ECLI:NL:RVS:2014:2036.

67 See about this: Slingenberg 2015.

68 Article 56 of the Aliens Act 2000. This provision only allows restrictions of liberty 'in the interests of public policy or national security'. The systematic use of restriction of liberty for families living in family locations seems to be in tension with these requirements.

69 Based on Article 54(f) of the Aliens Act 2000.

70 Kamerstukken II, 2011/12, 29,344, no. 85.

71 Kamerstukken II, 2011/12, 29,344, no. 86.

72 Kamerstukken II, 2011/12, 29,344, no. 85, p.
} 
The daily duty to report with the authorities of the shelter has not been laid down in any kind of law or regulation, nor are the consequences of failing to report. This has been confirmed by the Council of State. ${ }^{73}$

In response to a freedom of information request by journalists about violent situations in asylum seekers' centres, the organization that is managing the family locations, the $C O A$, published an internal regulation about dealing with incidents and sanctions in family locations at its website (Regeling afhandelen incidenten en maatregelen gezinslocaties). ${ }^{74}$ From this internal regulation, it appears that if a migrant does not meet his/her daily reporting obligation, this results in an official warning, the second time in a deduction of the weekly financial benefit and the third time in a deduction of the weekly financial benefit and a notification to the Aliens police. The Aliens police can decide, on the basis of such an 'incident', that there are sufficient grounds to detain the family, in order to prevent the family from absconding. ${ }^{75}$ Accordingly, the enforcement of the daily reporting obligation has a strong coercive character; violation of the obligation has serious consequences for the migrants. ${ }^{76}$

The absence of a legal basis for this coercive measure constitutes, in itself, a situation of domination. A basic condition for the rule of law, and for preventing domination, is that every use of coercive force is governed by the law, as has been discussed in Sect. 2 above. The absence of a legal basis for the daily reporting obligation is not just a matter of 'rule-implementing discretion' ${ }^{77}$ or, in other words, 'bureaucratic discretion', ${ }^{78}$ that is widespread and unavoidable in any legal system. Instead, it reflects a situation of 'strong discretion', where controlling rules are simply absent altogether, which is one of the two forms of discretion that cannot be reconciled with the rule of law, according to Lovett.

If this would be fixed, and a legal basis would be created for the daily reporting obligation, this would not, however, necessarily mean that domination would henceforth be absent. As has been discussed in Sect. 2 above, merely authorizing the use of force is not enough to prevent domination; it should also be assessed whether sufficient accountability mechanisms are available to prevent accountability discretion.

\footnotetext{
73 ABRvS 27 May 2014, ECLI:NL:RVS:2014:2036.

74 'Regeling afhandelen incidenten en maatregelen gezinslocaties', internal regulation, published in response to a WOB request of the Volkskrant, availabe at: (no. 3): https://www.coa.nl/nl/wob/wob-verzo ek-iz-incidenten-asielzoekerscentra [assessed 15 June 2020].

75 Vreemdelingencirculaire (Aliens Circular) 2000 Vc A5/2.4.

76 Adults living in a family location only receive a weekly financial benefit to buy food. They do not receive the 12,95 euro per person per week for clothing and other personal expenses that asylum seekers living in an asylum seekers center receive (Article 14(4) Rva 2005). Children living in a family location do receive the money for clothing and other personal expenses. This means that for example two parents with two children living in a family location receive 146 euro per week. To compare, NIBUD (National Institute for Family Finance Information) has calculated that the minimum costs for buying food for a family with two children between four and nine years old is 137,41 euro per week (https://www.nibud.nl/ consumenten/wat-geeft-u-uit-aan-voeding/, [last assessed: 15 June 2020]. This means that only very little money is available for buying clothing, sanitary products, public transport, school supplies etc. A deduction of the weekly financial benefits is, accordingly, a serious sanction.

77 Lovett, see Sect. 2 above.

78 See, e.g. Sager 2017.
} 
Such accountability mechanisms should at least to some extent be self-initiated or self-controlled. The less possibilities there are for migrants to exit, the more important this element of 'voice' is. Consequently, for establishing the degree of domination to which migrants living in family locations are subjected, the remainder of this section will analyse:

- options for migrant families without legal residence to exit the power of the state to which they are subjected in family locations (i.e. their level of dependency);

- whether there are legal mechanisms to contest the measures (i.e. whether there are legal remedies available); and

- the grounds that can be invoked to contest the measures (i.e. whether there are legal grounds stemming from autonomous legal sources, that are not primarily developed by the sovereign power that constrain the discretion of the authorities).

\subsection{Exit Options}

Migrant families without legal residence have three routes to leave the coercive power to which they are subjected in family locations: (1) leave the country altogether; (2) regularize their status and, for that reason, become eligible for other kind of state benefits; or (3) reject or leave the family locations and fend for themselves.

Benton has convincingly argued that the exit costs for leaving a country of residence depend on both the viability of a life elsewhere and the relative costs of leaving, which, on their part, depend on factors such as the economic and security situation in the country, existence of social ties, employment opportunities, skills, existence of debts to travel agencies or family members etc. ${ }^{79}$ For this reason, it is safe to assume that at least for part of the families living in family locations, the (objective and/or subjective) costs of leaving the Netherlands are high.

With regard to the option of regularization, there are possibilities, both on individual grounds, such as asylum, family life or medical reasons, as on the basis of a general amnesty. However, difficulties of proving continued residence; the existence of a 'genuine' relationship; new circumstances with regard to their asylum account; or the existence of a medical emergency; can hamper regularization options. Additionally, the existence of a criminal record or the absence of any identity documents can stand in the way. Hence, also for this exit route, it is safe to assume that it is not available for all migrants living in the state's family locations.

Since migrants without legal residence are not eligible for any kind of statefunded shelter or other kind of basic needs, the third exit route is not really a viable option either. As the Hoge Raad has stressed in its judgment, state-funded shelter is necessary for these families in order to prevent a humanitarian emergency. For migrants who do not have a strong social network in the Netherlands, living in these family locations is the only way to ensure basic needs for their children.

79 Benton 2014. 
Due to these different constraints, for many migrants living in family locations, exit from the power of the state in the locations is only possible at high cost. In order to prevent situations of domination, it is, therefore, important that migrants living in family locations are able to hold the authorities accountable for their use of discretionary power.

\subsection{Possibilities to Contest}

The fact that the daily reporting obligation has no legal basis, would normally entail that no administrative legal protection is available, as there is no formal administrative 'decision'. However, with regard to migrants, an exception exists. Article 72(3) of the Aliens Act 2000 provides that an act of the administrative authority in respect of a person in his capacity of alien should be equated with a formal administrative decision for the purposes of legal protection.

Districts courts have ruled differently as regards the question whether the daily reporting obligation for migrants in family locations qualifies as such an act and should, therefore, be equated with an administrative decision for the purposes of legal protection. The District Court of Amsterdam ruled that the parliamentary history of Article 72(3) of the Aliens Act 2000 shows that an act should be based on the Aliens Act in order to be equated with an administrative decision. Since the daily reporting obligation is not based on the Aliens Act 2000, it could not be equated with an administrative decision according to the District Court of Amsterdam. ${ }^{80}$ The District Court of the Hague held as well that the daily reporting obligation cannot be equated with an administrative decision on the basis of Article 72(3) of the Aliens Act $2000 .{ }^{81}$ A year later, however, that Court arrived at the opposite conclusion, and ruled that the application of the daily reporting obligation is an act concerning a person in his capacity as an alien, regardless of the absence of a basis in the Aliens Act, and should, therefore, be equated with an administrative decision. ${ }^{82}$ The Council of State, ultimately, ruled that the daily reporting obligation can be equated with an administrative decision on the basis of Article 72(3), since the purpose of this rule is to entrust all legal protection of migrants to administrative judges. ${ }^{83}$

This means that even though this was not entirely clear from the start, there is a legal option to contest the daily reporting obligation, or the refusal to exempt a person from this obligation. Similar to regular administrative decisions, in order to contest acts that are equated with an administrative decision, a formal objection should be lodged to the secretary of state. If this formal objection is declared unfounded by the secretary of state, it is possible to lodge an appeal against this decision with a District Court and a higher appeal with the Council of State. ${ }^{84}$

\footnotetext{
80 Rb Amsterdam 19 November 2013, ECLI:NL:RBDHA:2013:19,075.

81 Rb Den Haag 3 October 2012, JV 2013/56.

82 Rb Den Haag 16 October 2013, ECLI:NL:RBDHA:2013:13,709.

83 ABRvS 27 May 2014, ECLI:NL:RVS:2014:2036; ABRvS 20 January 2015, ECLI:NL:RVS:2015:178.

${ }^{84}$ Articles 7:1, 8:1 and 8:104 Algemene Wet Bestuursrecht.
} 


\subsection{Grounds of Contestation}

The possibility of contesting an act of the authorities is only effective if there are grounds on which the act can be contested and the authorities can be held accountable for their actions. In line with the fundamental 'duality of law', as discussed in Sect. 2, it is important that these grounds stem from other legal sources, not primarily developed by the sovereign power. The Dutch constitution does not contain a right to freedom of movement or to choose a place of residence. This section will, therefore, analyse to what extent other rules i.e. human rights law, European Union law and/or general principles of law, constrain the rule-makers' discretion.

Both the European Convention of Human Rights (ECHR) and the International Covenant on Civil and Political Rights (ICCPR) contain the right to freedom of movement and the freedom to choose a residence. ${ }^{85}$ The scope of these provisions is, however, limited to persons 'lawfully within the territory of a state'. The European Court on Human Rights (ECtHR) has ruled that the phrase 'lawfully within the territory' refers to the domestic law of the State concerned:

'It is for the domestic law and organs to lay down the conditions which must

be fulfilled for a person's presence in the territory to be considered "lawful" 86

In addition, the Court held that migrants can only be regarded as "lawfully" in the territory as long as they comply with the conditions to which their admission and stay are subjected. In Omwenyeke, an asylum seeker complained that the obligation imposed on him to reside within an assigned district was in violation of his right to freedom of movement. The Court, however, merely noted that his provisional authorization to stay in Germany was conditional on his stay in the assigned district. Since he had left that district without permission, he was not 'lawfully within the territory', and Article 2 of Protocol 4 did not apply. This means that the Court did not scrutinize the residence restriction as such, but used it to stress the limited personal scope of the right to freedom of movement.

The families living in the Dutch family locations do not have authorization to take up residence in the Netherlands; nor do the majority have provisional authorization to stay on the territory. For this reason, the right to freedom of movement as laid down in the ECHR and ICCPR is inapplicable and, accordingly, does not constrain the authorities' discretion.

The same is true with regard to other human rights. In Omwenyeke, the asylum seeker also complained that the residence restriction violated his right to respect for his private life but this complaint was declared manifestly ill-founded by the Court, without any further deliberation. ${ }^{87}$ In addition, a residence restriction or a daily reporting obligation is unlikely to reach the threshold of inhuman and degrading treatment, which is forbidden under Article 3 ECHR and 7 ICCPR. In Hunde v. the

\footnotetext{
85 Article 2 of Protocol 4 to the ECHR and Article 12 ICCPR.

86 ECtHR 20 November 2007, 44,294/04 (Omwenyeke v. Germany), para. 1.

87 Also in a Dutch case, the court rejected the claim based on Article 8 ECHR without any deliberation, see Rb Rotterdam 11 July 2017, AWB 17/11,830, Migratieweb ve17001648.
} 
Netherlands, a rejected asylum seeker complained about his poor living conditions in the light of Article 3 ECHR. The Court, in holding the complaint manifestly illfounded, noted inter alia that the applicant had 'the possibility to seek admission to a centre where his liberty would be restricted' ${ }^{88}$ Apparently, accommodation under the condition of liberty restriction is a way to prevent inhuman or degrading treatment, and does not constitute such treatment itself.

In EU law, the relevant instrument is the EU Returns Directive, ${ }^{89}$ since the migrants living in family locations are, generally, subjected to an obligation to return to their country of origin. The Returns Directive allows Member States to impose obligations to 'regular reporting to the authorities' and 'to stay at a certain place' during the period for voluntary return, that Member States have to grant to illegally staying migrants when they issue a return decision. ${ }^{90}$ The purpose of imposing such an obligation is to avoid the risk of absconding. This obligation may also be imposed during the time that the removal of the migrant concerned is postponed. ${ }^{91}$ No futher conditions or procedural safeguards apply with regard to the issuance of these obligations. ${ }^{92}$ The Return Directive, therefore, does not constrain the ability of Dutch authorities to impose a daily reporting obligation on the families living in family locations. Moreover, EU law allows member states to use such residence obligations and reporting obligations as a pathway to detention. The Returns Directive allows for detention if there is a 'risk of absconding'. ${ }^{93}$ The Returns Directive defines 'risk of absconding' as 'the existence of reasons in an individual case which are based on objective criteria defined by law to believe that a third-country national who is the subject of return procedures may abscond'. ${ }^{94}$ This means that it is up to Member States to lay down objective criteria in their national legislation for establishing whether a risk of absconding exists. In a case about the meaning of the term 'absconding' in the Dublin Regulation, the Court of Justice held that, 'in order to ensure the effective functioning of the Dublin system and the achievement of its objectives,' the authorities do not have to prove that the migrant concerned deliberately evades the reach of those authorities, as this would cause the authorities considerable difficulties. ${ }^{95}$ Accordingly, non-compliance with a reporting obligation can be used by Member States as a criteria for establishing a 'risk of absconding', which is a ground for detention. This means that EU law not only allows member states to

\footnotetext{
${ }^{88}$ ECtHR 5 July 2016, 17,931/16, para 56 and 59.

89 Directive 2008/115/EC of the European Parliament and of the Council of 16 December 2008 on common standards and procedures in Member States for returning illegally staying third-country nationals.

90 Article 7(3) of Directive 2008/115/EC. The period of voluntary return can be extended by member states.

91 Article 9(3) of Directive 2008/115/EC.

92 Article 12) of Directive 2008/115/EC, on procedural safeguards, only applies to return decisions, entry-ban decisions and decisions on removal, not to decisions to impose certain obligations to avoid the risk of absconding. Article 15 contains procedural safeguards for detention only.

93 Article 15(1)(a) of Directive 2008/115/EC.

94 Article 3(7) of Directive 2008/115/EC.

95 CJEU 19 March 2019, Case C-163/17 (Jawo).
} 
impose reporting obligations on unlawfully residing migrants, but also allows member states to use a significant degree of coercion in order to secure compliance.

The EU Charter on Fundamental Rights does not constrain member states any further in this regard, since freedom of movement only applies to EU citizens and 'may be granted' to nationals of third countries 'legally resident in the territory of a Member State'. 96

Since international human rights law and EU law are inapplicable or do not constrain the authorities, the only grounds for contestation are general legal principles. Indeed, in the scarce Dutch case law about the daily reporting obligation, migrants merely rely on general principles of administrative law, such as proportionality and justice. Since these principles do not originate from specific norms, tailored to the issue of restrictions on freedom of movement, judges only cursorily examine such arguments.

In a case from 2012, residents of the family location in Katwijk claimed that the reporting obligation should be changed from a daily one to a weekly one. The district court of the Hague merely held:

'in itself it is understandable that the duty to report is experienced as difficult, but [since the reasons for imposing this duty appear to be reasonable and justified], this is insufficient for qualifying the duty as unlawful'. 97

In a 2018 case, residents of the family location in Goes also claimed that the daily duty to report was too burdensome, and that a weekly reporting obligation would be more appropriate for their situation, since they are dependent on the shelter in the family location and had, therefore, no intentions to abscond. The district court of Middelburg did not deal with this claim. The court merely referred to the discussion of the claim against the restrictions of the applicants freedom to the territory of the municipality of Goes, which does have a basis in Dutch law. The court just added to this that it is possible to request an exemption from the daily reporting obligation, for example to visit their lawyer. ${ }^{98}$

There are no other (published) cases about the daily reporting obligation.

\section{Conclusion}

[T]he populations we are trying to describe, those who have become effectively stateless, are still under the control of state power. In this way, they are without legal protection but in no way relegated to a "bare life": this is life

\footnotetext{
96 Article 45 Charter. Arguably, this provision has an even more limited personal scope as articles 2 of Protocol 4 ECHR and Article 12 ICCPR, as the charter provision requires lawful residence and the two human rights conventions only lawful presence (see on the different meanings of these terms Slingenberg 2014).

97 Rb Den Haag 7 November 2012, ECLI:NL:RBSGR:2012:BY2400 (translation mine).

98 Rb Middelburg 2 May 2018, ECLI:NL:RBDHA:2018:5314.
} 
steeped in power. And this reminds us, crucially, that power is not the same as law, 99

For migrants living in family locations in the Netherlands, the provision of basic needs is made conditional on their subjection to coercion: a daily reporting obligation. By imposing this obligation, the authorities are able to change what these migrants might otherwise prefer to do and have a significant impact on migrants' ability to establish their daily structure, and, arguably, on their autonomy and dignity. This kind of social power is coercive as it is based on conditional threats: noncompliance with the daily reporting obligation has severe consequences for migrants (loss of money that is needed for meeting basic needs and a ground for detention). This Dutch practise fits in a European trend towards more coercive and restrictive inclusionary practises for irregular migrants.

This paper has provided a rule of law framework with which to analyse such practises. Authors like Lovett, Benton and Palombella have convincingly argued how the rule of law, in their conceptualization, is necessary to realize the neorepublican concept of freedom as non-domination. Non-domination, or the absence of mastery by others, is a primary good in neorepublican theory, that should be available to everyone. Drawing on their writings, this paper has conceptualized domination as the situation in which a person is subjected to coercive rules from which s/he can only exit at high costs and that have no legal basis and/or cannot be contested in court on the basis of laws stemming from legal sources that are somehow independent from the sovereign power. The second part of the paper applied this concept of domination to the daily reporting obligation imposed on migrants living in Dutch family locations. It demonstrated the relevance and consequences of this concept by identifying two fundamental rule of law problems.

First, this paper revealed that the daily reporting obligation has no legal basis in Dutch law. This means that the power of the authorities is not constrained specifically by Dutch law i.e. by laying down exceptions, time limits etc. The authorities have full discretion in subjecting migrants to reporting obligations; they can establish the frequency, the time slot, and can exempt migrants from the obligation at will. Since migrants are highly dependent on shelter in these family locations, as exit options only exceptionally exist, this absence of a legal basis, a case of 'strong discretion', creates for most of these migrants a situation of sheer domination.

Even if, however, an adequate legal basis would be created for the daily reporting obligation, this would not prevent situations of domination. This paper has shown that for preventing domination, mere legality is not enough. In line with Lazar's and Palombella's argumentation, it should also be avoided that the rules themselves turn into a tool of domination, a mere instrument to legitimize (concentrations of) power. This paper has argued, drawing mainly on Benton and Palombella, that in order to prevent domination, it is also necessary that rule-makers can be held accountable for their use of coercion. Especially if exit options are scarce or non-existent, this means, as I have argued, that people should be able

99 Judith Butler in 'Who sings the nation state' (2010), p. 8-9. 
to contest the adoption and application of coercive rules before a judge, based on legal grounds that stem from sources sufficiently independent from the sovereign power.

The second problem identified in this paper is that relevant standards of human rights law and of EU law are either inapplicable, or do not constrain the authorities in any meaningful way. This means that the only grounds for contestation that migrants living in family locations can invoke are general principles of EU law or Dutch administrative law, such as the proportionality principle. The limited Dutch case law available shows that judges only briefly and superficially deal with such claims.

However, in the absence of applicable constitutional or human rights norms, domination can only be prevented if some other law is available that does not stem from gubernaculum, from the legitimate sovereign law, but from jurisdictio, a law otherwise developed. From a rule of law perspective, judges should protect the opposition of these two sides of the law, in order to prevent the law from becoming a sheer instrument of the preferences of the sovereign power. Instead of waving away arguments based on the principle of proportionality, this would, for example, mean that judges use this principle as a real counterbalance to the gubernaculum side of the law, by asking questions and critically examining the justification, on an individual basis, for the use of coercive power in the family locations. Even though this would not necessarily mean that migrants cannot be subjected anymore to reporting obligations, it would ensure more procedural justice and could imply some constraints on the sovereign power, e.g. as regards time limits, frequency and exceptions to the daily reporting obligation.

This Dutch example shows how the protection of freedom as non-domination, conceptualized from a rule of law perspective, sets more demanding criteria for the (courts of) law than the protection of human rights. At the same time, it does not require non-interference or elaborate positive obligations from the state. This framework does not ensure irregular migrants' freedom as self-mastery (for which access to legal residence and/or economic independence would, arguably, be required) but it does ensure their fundamental freedom in terms of absence of mastery by others. While this paper has applied this framework to spatial restrictions imposed on irregular migrants, it is relevant for the evaluation of other coercive practises for irregular migrants as well, such as the forced collection of biometric data ${ }^{100}$ or seizure of digital devices ${ }^{101}$. For irregular migrants, who do not have the right to reside in the territory, but who are entirely under the control of state power, non-domination as conceptualized in this paper provides, in my view, a necessary framework of review for such coercive practises, that ensures a kind of protection that is currently lacking.

\footnotetext{
100 Campesi 2018

101 Latonero and Kift 2018
} 
Acknowledgements The author would like to thank Frank Lovett, Mentko Nap, Bas Schotel, Wouter Veraart and the anonymous reviewers for their helpful comments on earlier drafts. An earlier version of this article was presented at the 2020 winter meeting of the Netherlands Association for Philosophy of Law and at the 2020 Vakgroepdag of the department of Constitutional, Administrative Law and Public Administration of the University of Groningen.

Funding The research for this article is funded by a VENI grant of the Dutch Research Council (Nederlandse Organisatie voor Wetenschappelijk Onderzoek, NWO).

Data availability Not applicable.

Code availability Not applicable.

\section{Compliance with ethical standards}

Conflicts of interest Not applicable.

Open Access This article is licensed under a Creative Commons Attribution 4.0 International License, which permits use, sharing, adaptation, distribution and reproduction in any medium or format, as long as you give appropriate credit to the original author(s) and the source, provide a link to the Creative Commons licence, and indicate if changes were made. The images or other third party material in this article are included in the article's Creative Commons licence, unless indicated otherwise in a credit line to the material. If material is not included in the article's Creative Commons licence and your intended use is not permitted by statutory regulation or exceeds the permitted use, you will need to obtain permission directly from the copyright holder. To view a copy of this licence, visit http://creativecommons.org/licen ses/by/4.0/.

\section{References}

Arnold S, Harris JR (2017) What is arbitrary power? J Political Power 10:55-70

Benton M (2010) The Tyranny of the Enfranchised Majority? The Accountability of States to their NonCitizen Population. Res Publica 16:397

Benton M (2014) The problem of denizenship: a non-domination framework. Crit Rev Int Soc Political Philosophy 17:49-69

Blunt GD (2015) On the source, site and modes of domination. Journal of Political Power 8:5-20

Blunt GD (2020) The case for epistocratic republicanism. Politics 40:363-376

Bosniak L (2006) The citizen and the Alien: dilemmas of contemporary membership. Princeton University Press, Princeton

Campesi G (2018) Seeking asylum in times of a crisis: reception, confinement and detention at europe's southern border. Refugee Surv Q 37:44-70

Da Lomba S (2011) Irregular migrants and the human right to health care: a case-study of health-care provision for irregular Migrants in France and the UK. Int J Law Context 7:357-374

Dembour MB (2015) When humans become migrants. Study of the European court of human rights with an inter-American counterpoint. Oxford University Press, Oxford

European Council on Refugees and Exiles (2018) Boundaries of liberty Asylum and de facto detention in Europe.Asylum Information Database.

European Council on Refugees and Exiles (2020a) Country Report: Greece. Asylum Information Database.

European Council on Refugees and Exiles (2020b) Country Report: Germany. Asylum Information Database.

Fine S (2014) Non-domination and the ethics of migration. Crit Rev Int Soc Political Philosophy 17:10-30

Hovdal-Moan M (2014) Unequal residence statuses and the ideal of non-domination. Crit Rev Int Soc Political Philosophy 17:70-89 
Kapuy K (2011) The social security position of irregular migrant workers. New Insights from National Social Security Law and International Law Intersentia, Cambridge/Antwerp/Portland

Kreichauf R (2018) From forced migration to forced arrival: the campization of refugee accommodation in European cities. Comparative Migration Stud 6:7. https://doi.org/10.1186/s40878-017-0069-8

Kumm M (2010) The idea of socratic contestation and the right to justification: the point of rights-based proportionality review. Law Ethics Hum Rights 4:141-175

Latonero M and Kift P (2018) On digital passage and borders: refugees and the new infrastructure for movement and control. Social Media + Society, doi: 10.1177/2056305118764432.

Lovett F (2010) A general theory of domination \& Justice. Oxford University Press, Oxford

Lovett F (2016) A Republic of Law. Cambridge University Press, Cambridge

Lovett F (2020) A republican argument for the rule of law. Crit Rev Int Soc Political Philosophy. https:// doi.org/10.1080/13698230.2020.1737473

Lovett F, Pettit P (2009) Neorepublicanism: A Normative and Institutional Research Program. Annual Review of Political Science 12:11-29

Majcher I, Flynn M and Grange M (2020) Immigration Detention in the European Union. In the Shadow of the "Crisis". Springer, Dordrecht.

McCammon C (2015) Domination: a rethinking. Ethics 125:1028-1052

McDonough P (2009) Revisiting Germany's residenzpflicht in light of modern E.U. Asylum law. Michigan J Int Law 30:515-554

Moreno-Lax V (2018) The EU humanitarian border and the securitization of human rights: the 'rescuethrough-interdiction/rescue-without-protection' Paradigm. J Common Market Stud 56:119-140

Noll G (2010) Why human rights fail to protect undocumented migrants. Euro J Migration Law $12: 241-272$

Palombella G (2009) The Rule of Law and its Core. In: Palombella, G and Walker, N (eds) Relocating the Rule of Law. Hart Publishing, Oxford.

Palombella G (2010) The rule of law as institutional ideal. Comp Sociol 9:4-39

Palombella G (2018) Illiberal, Democratic and Non-Arbitrary? Epicentre and Circumstances of a Rule of Law Crisis. Hague Journal on the Rule of Law 10:5-19

Palombella G (2019) Two threats to the rule of law: legal and epistemic (between technocracy and populism). Hague J Rule Law 11:383-388

Pettit P (1997) Republicanism: A theory of freedom and government. Oxford University Press, Oxford

Pettit P (2012) On the people's terms. A republican theory and model of democracy. Cambridge University Press, Cambridge

Raz J (1979) The rule of law and its virtue, in: the authority of law: essays on law and morality, Oxford University Press, Oxford.

Sager A (2017) Immigration enforcement and domination: an indirect argument for much more open borders. Political Res Q 70:42-54

Schoukens P, Buttiens S (2017) Social protection of non-removable rejected asylum-seekers in the EU: a legal assessment. Euro J Soc Security 19:313-334

Shapiro I (2012) On non-domination. University of Toronto Law Journal 62:293-335

Slingenberg L (2014) The reception of asylum seekers under international law. Between sovereignty and equality. Hart Publishing, Oxford

Slingenberg L (2015) Onrechtmatig verblijvende vreemdelingen en recht op respect voor een thuis. Asiel\&Migrantenrecht 8:348-350

Spencer S, Hughes V (2015) Fundamental rights for irregular migrants: legal entitlements to healthcare and school education across the EU 28. Euro Hum Rights Law Rev 6:604-616

Tamanaha, BZ (2012) The history and elements of the rule of law. Singapore J Legal Stud 232-247.

Tazzioli M (2020) Governing migrant mobility through mobility: containment and dispersal at the internal frontiers of Europe. Environ Plan C 38:3-19

Vinx L (2009) Republicanism and judicial review. University of Toronto Law Journal 59:591-597

Waldron J (2008) The concept and the rule of law. Georgia Law Rev 43:1-61

Walen A (2009) Judicial review in review: a four-part defense of legal constitutionalism a review essay on Political Constitutionalism. Int J Constitutional Law 7:329-354

Publisher's Note Springer Nature remains neutral with regard to jurisdictional claims in published maps and institutional affiliations. 